\title{
The Effect of Absenteeism, Workload and Job Satisfaction on Cost Reduction: Case Study at IFRC - CCST
}

\author{
Dewi Rosiani ${ }^{1}$, Arief Wibisono Lubis ${ }^{2}$ \\ (dewi.rosiani8@yahoo.com, arief_wibisono_lubis@yahoo.com) \\ ${ }^{1}$ Master of Management, FEB Universitas Indonesia, Jakarta, Indonesia \\ ${ }^{2}$ Department of Management, FEB Universitas Indonesia, Jakarta, Indonesia
}

\begin{abstract}
This research aims to examine the effect of absenteeism, workload, and job satisfaction on cost reduction in the context of a non-profit organization as mentioned above. The research method uses causal descriptive (related to the statement of each variable in the study) and causal associative research methods (aims to determine the effect of WLB on cost reduction). Data analyzed were units of data originating from individual IFRC staff, collected through questionnaire research instruments using a Likert scale. From the analysis result showed that job satisfaction is significantly associated with cost reduction in the organization, while absenteeism and workload do not have any significant relationship with cost reduction. Thus the implication is IFRC needs to improve work life balance program to reduce cost in the organization through increasing employees' job satisfaction.
\end{abstract}

Keywords: Absenteeism, Workload, Job Satisfaction, Cost Reduction, WorkLife Balance.

\section{Introduction}

The International Federation of Red Cross and Red Crescent Societies (IFRC) is a non-profit organization engaged in the field of humanity, formed since 1919 in Paris. IFRC takes action before, during and after a disaster or health emergency without discrimination on nationality, race, religion, class or political opinion. IFRC staff should be available at all times in terms of disaster management, so that a high level of staff absenteeism must be reduced and should not occur, because it has a major impact on the cost issues that IFRC is responsible to humanitarian aid donors and other stakeholders. HR and Finance do have a very close relationship in several aspects, this is one of them.

In normal situations, all IFRC staff have many work responsibilities, for example providing health education and disaster preparedness to the general public. In the event of a disaster or health emergency, almost all staffs will work 
long periods of time with very high workloads, adjusting rehabilitation completion targets. Equitable distribution of workload according to position must be considered, so there is no work fatigue due to overwork, which can potentially cause staff illness or even work accidents. If this happens, it will certainly incur additional costs such as paying overtime for other staff to help complete work targets, incurring costs for the recruitment of replacement staff (daily worker, internship, or assistant staff).

Previously, the level of absenteeism and staff turnover was very high at IFRC, which made the HR team work extra hard in recruiting within urgent time, since the needs of employees were very high especially in the event of a disaster. In this regard, from April 30, 2019, IFRC HR began implementing a work-life balance program, as a form of full support for its staff in carrying out humanitarian missions. This program is considered important because the organization realizes that staff not only face roles and problems at work, but also outside their work. The size of the balance is indeed different for each individual, because of differences in life and priorities in his life. Therefore, organizations must consider what kind of work-life balance program to be implemented.

The following are the work-life balance program benefits for employees [1]: (1) increased job satisfaction; (2) increased job security; (3) increase control over work-life environment; (4) reduced levels of work stress; and (5) increasing physical and mental health. As for the company [1]: (1) reducing the level of absenteeism and delays; (2) increase productivity; (3) employee commitment and loyalty; (4) increasing customer retention; and (5) reduced employee turnover. Benefits for this organization can be a source of unnecessary cost reduction, thus at the end, the organization could provide even more benefits to staff.

The work-life balance program implemented by IFRC includes: provide work time flexibility, working from home, 24 days leave a year, nursery rooms for breastfeeding and break out rooms to release fatigue at work, and familyfriendly policies such as special leave (maternity leave, male staff leave to accompany the wife giving birth, leave accompanying sick parents / close relatives, etc.), holding informal activities such as outbound (skills development activities) and also gymnastics, yoga and other hobby distribution programs while providing diverse needs serving coffee in the office pantry room.

Meanwhile, to implement a work-life balance policy, the following costs can arise[2], namely:

- direct costs, such as payment of parental leave or providing equipment for telecommuters (flexibility of time and place to work with communication technology support); 
- indirect costs, related to temporary replenishment of absences and temporary reductions in productivity arising from disturbances.

- costs associated with implementing work-life balance policies

The organizations may experience difficulties in assessing the real impact of work-life balance policies because it is easier to identify and measure costs than benefits. One of the organizational successes is the creation of job satisfaction among staff in the organization, which will also have a positive impact on staff work. This is in line with the opinion [3], in which maximizing employee satisfaction by making employees feel "valuable" will form the core of the asset / human resource policy.

The success or failure of an organization largely depends on the quality, positive contribution and creativity of the people who work in it. To achieve organizational goals, they need to recruit people with the necessary skills, qualifications, and experience [4]. If human resource is treated as an asset, then every salary, wages, benefits to the facilities provided are investments and not costs. Since they are investments, the impact certainly cannot be felt immediately at that time.

Before implementing a WLB program, the staff turnover rate was very high in IFRC. The HR recruitment team should work extra hard within urgent target time, since the needs of new staff are very high, especially when in a state after a disaster or health emergency. This very high staff turnover results significant additional costs incurred by the Finance department. The purpose of this case study is to analyze the effect of absenteeism, workload and job satisfaction on cost reduction in IFRC Country Cluster Support Team staff in Indonesia, with the research question are :

1. Knowing that absenteeism has a negative relationship with cost reduction

2. Knowing that workload has a negative relationship with cost reduction

3. Knowing that job satisfaction has a positive relationship with cost reduction

4. Knowing that WLB has a significant positive effect on cost reduction

The research conceptual model that becomes the reference is the research presented by Deborah, which clearly shows a positive correlation to Cost Reduction. This study found that a reduced workload would reduce the potential for conflict between work and family; and reduced absenteeism and high levels of job satisfaction have been shown to reduce costs to the organization.

As supporting data research, Figure 1.1 presents the IFRC Headcount Data Diagram during 2019, which shows the difference in the level of absenteeism between the first and second semester (six months) of staff in the IFRC office. 
The difference in this attendance levels is strongly influenced by the implementation of work-life balance program since April 30, 2019.

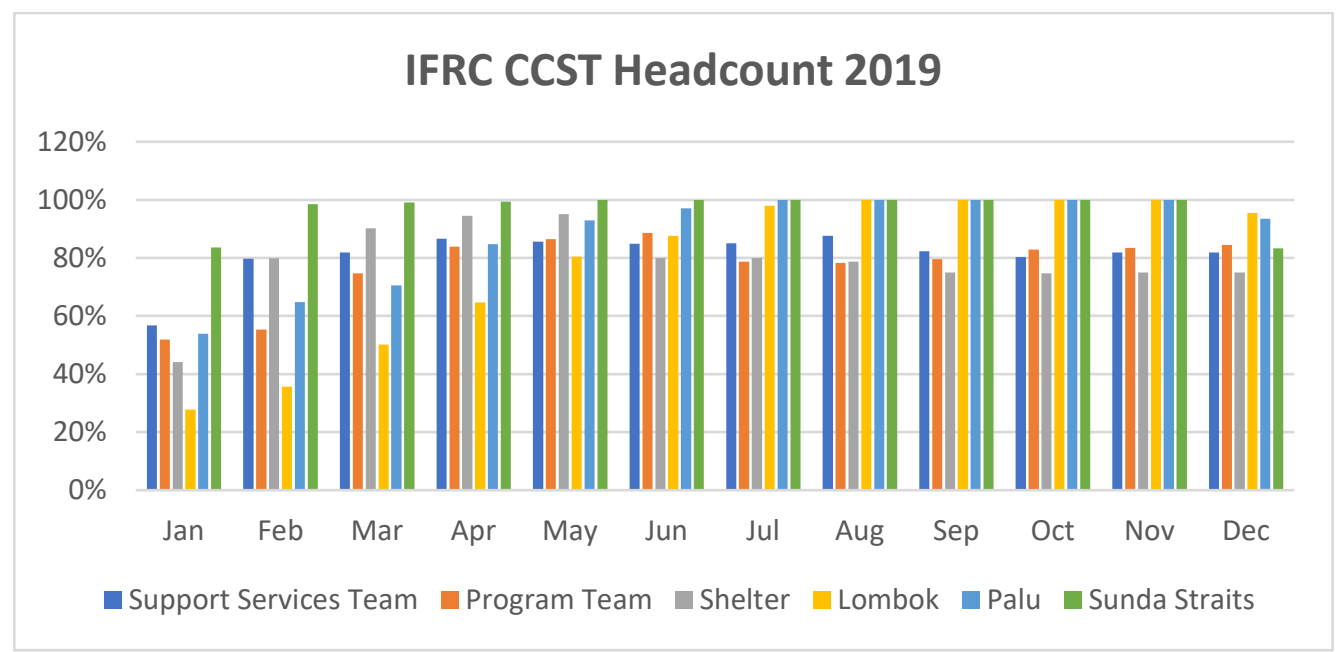

Figure 1.1 Headcount Data Diagram 2019 IFRC CCST Source: HR IFRC

Figure 1.2 Diagram Variable Cost 2019 IFRC CCST presents an increase in variable cost reduction after the implementation of work-life balance program. And this is based on data on Table 1.1 Data Budget vs Actual 2019 IFRC CCST as follows:

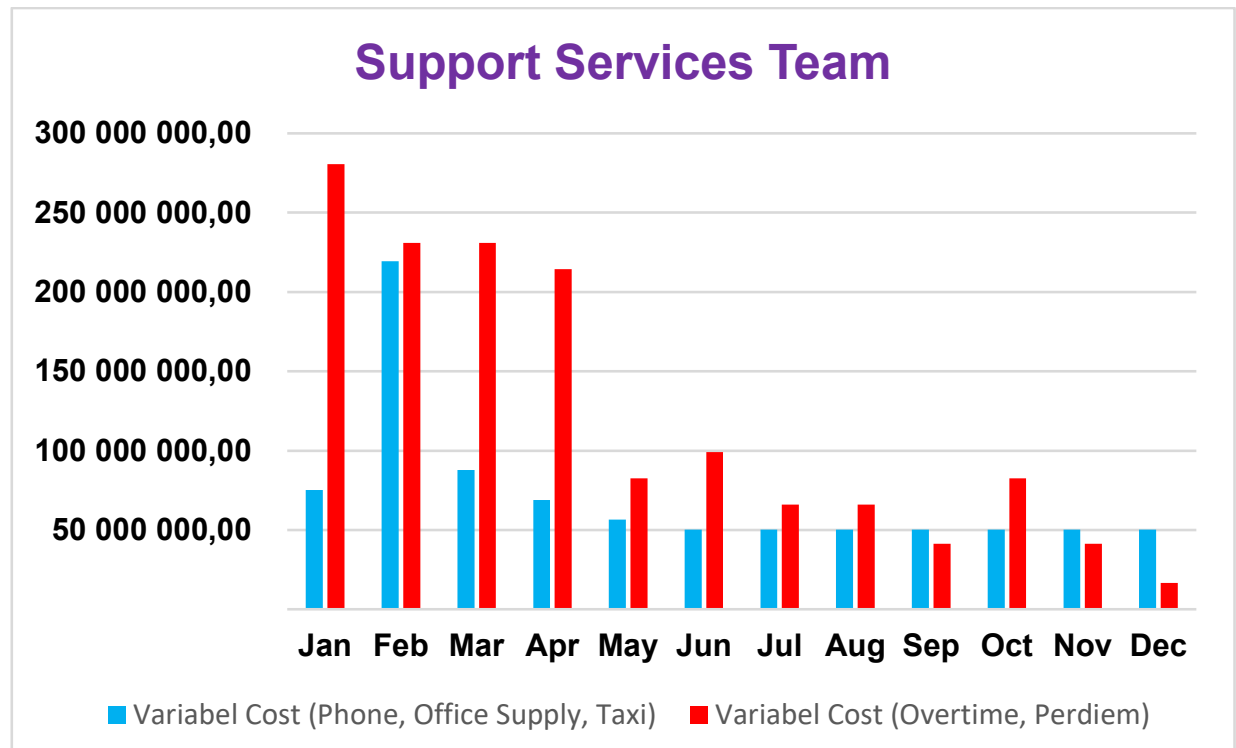


Figure 1.2 Diagram Variable Cost 2019 IFRC CCST Source: HR IFRC

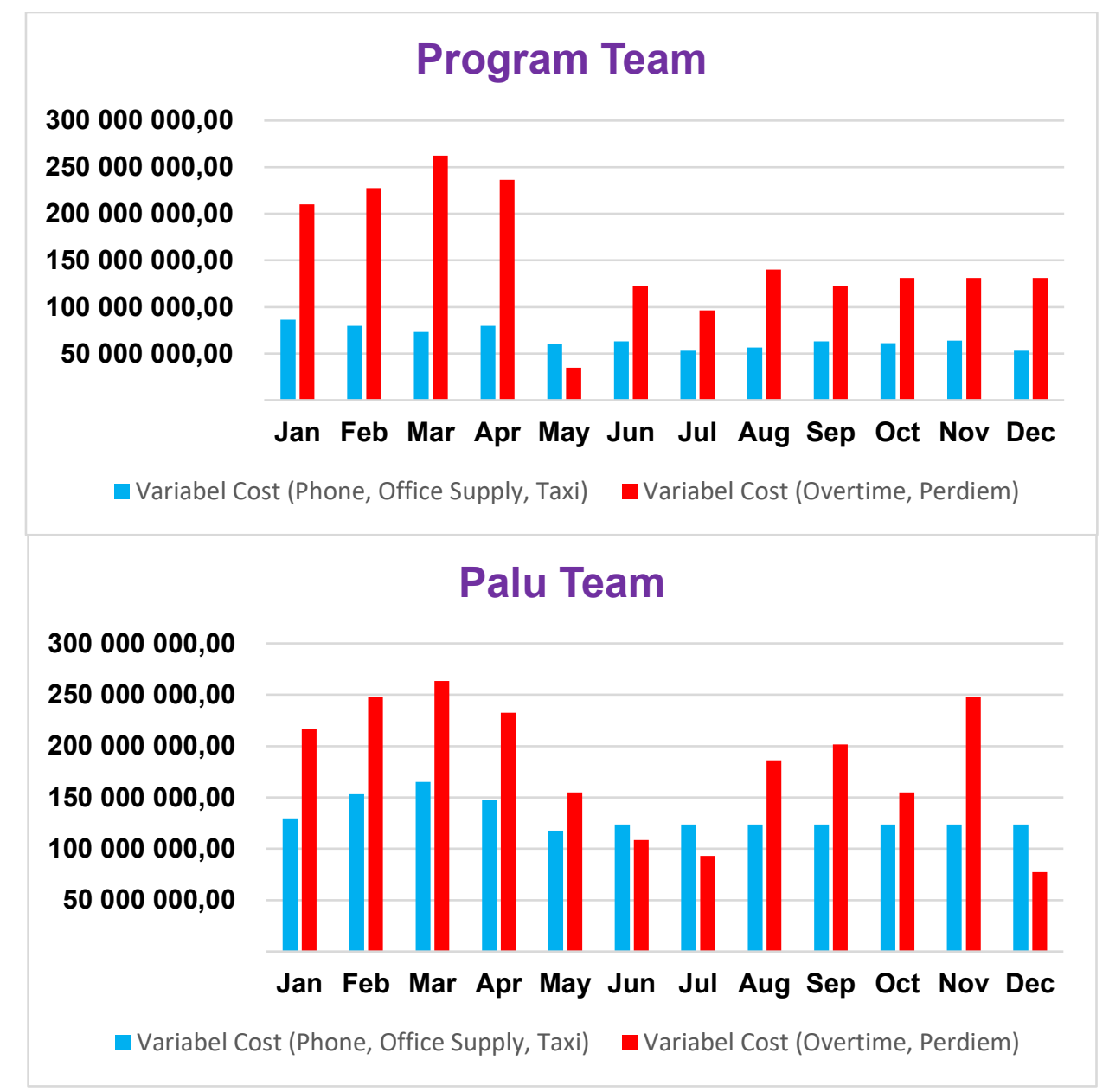




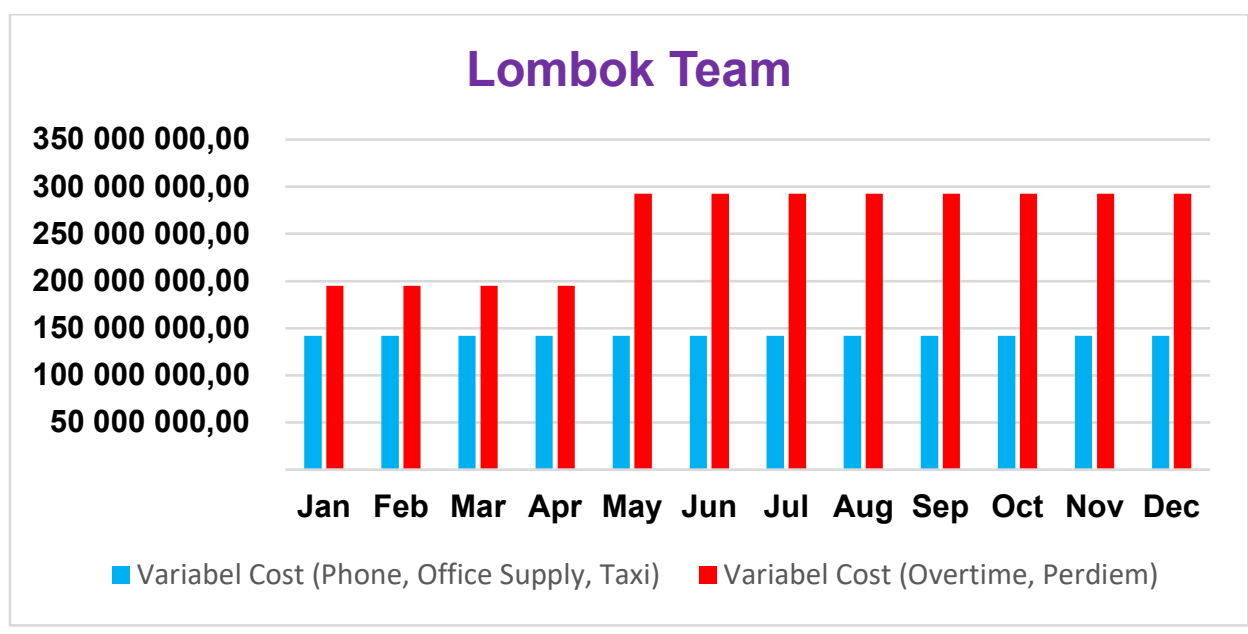

Figure 1.2 Diagram Variable Cost 2019 IFRC CCST Source: HR IFRC 
Table 1.1 Data Budget vs Actual 2019 IFRC CCST

Monthly Budget - Support Services Team

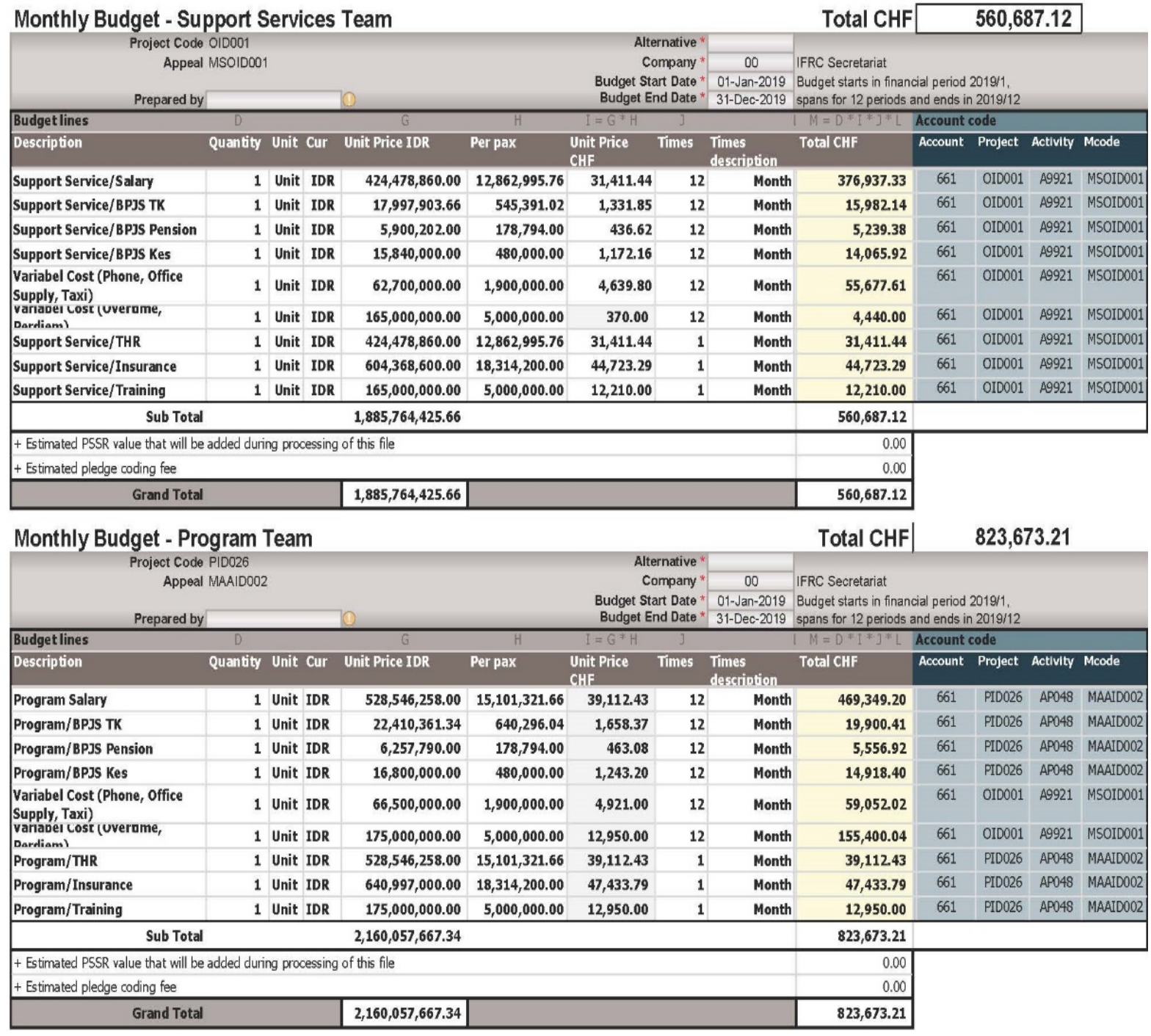




\begin{tabular}{|c|c|c|c|c|c|c|c|c|c|c|c|c|}
\hline & IDR & IDR & IDR & $\overline{I D R}$ & IDR & IDR & IDR & IDR & $\overline{I D R}$ & $\begin{array}{l}\mathrm{IDR} \\
\end{array}$ & IDR & IDR \\
\hline $\begin{array}{l}\text { Spresed } \\
\text { whothod }\end{array}$ & P01 & P02 & P03 & PO4 & P05 & PO5 & P07 & PQB & PO9 & $P 10$ & P11 & P12 \\
\hline Monthly & $340,478,860,00$ & $376,478,960,00$ & $384,478,860.00$ & $400,478,860.00$ & $392,478,860.00$ & $384,478,860,00$ & $392,478,960,00$ & $400,478,960.00$ & $384,478,860,00$ & $384,478,850.00$ & $376,478,860.00$ & $376,478,860.00$ \\
\hline Monthly & $14,436,303.66$ & $15,962703.66$ & $16,301,903.66$ & $16,980,303.66$ & $16,641,103.66$ & $16,301,903.66$ & $16,641,103.66$ & $16,960,303.66$ & $16,301,903.66$ & $16,301,903.66$ & $15,962,703.66$ & $15,962,703.66$ \\
\hline Monthly & $4,469,850.00$ & $4,827,438.00$ & $5,006,232.00$ & $5,363,820.00$ & $5,185,026.00$ & $5,006,23200$ & $5,185,026.00$ & $5,363,820.00$ & $5,006,23200$ & $5,006,232.00$ & $4,827,438.00$ & $4,827,438.00$ \\
\hline Monthly & $12,000,000.00$ & $12,960,000.00$ & $13,440,000.00$ & $14,400,000.00$ & $13,920,000.00$ & $13,440,000.00$ & $13,920,000.00$ & $14,400,000.00$ & $13,440,000.00$ & $13,440,000.00$ & $12,960,000.00$ & $12,960,000.00$ \\
\hline Monthly & $75,240,000,00$ & $219,450,000.00$ & $87,780,0000.00$ & $68,970,000.00$ & $56,430,000,000$ & $50,160,000,00$ & $50,160,000,00$ & $50,150,000.00$ & $50,160,000,00$ & $50,160,000,00$ & $50,160,000,00$ & $50,160,000,00$ \\
\hline Monthly & $280,500,000,00$ & $231,000,000,00$ & $231,000,000.00$ & $214,500,000,00$ & $82,500,000.00$ & $99,000,000,00$ & $66,000,000,00$ & $66,000,000,00$ & $41,250,000,00$ & $82,500,000.00$ & $41,250,000,00$ & $16,500,000,00$ \\
\hline All at once & & & & & $424,478,860.00$ & & & & & & & \\
\hline All at once & $604,368,6000,00$ & & & & & & & & & & & \\
\hline \multirow[t]{2}{*}{ Manual } & $15,000,000,00$ & $15,000,000,00$ & $15,000,000,00$ & $15,000,000,00$ & $10,000,000,00$ & $15,000,000,00$ & $15,000,000,00$ & $15,000,000,00$ & $15,000,000,00$ & $15,000,0000,00$ & $10,000,000,00$ & $10,000,0000,00$ \\
\hline & $1,346,493,613,66$ & $875,679,001,66$ & $753,006,995,66$ & $735,692,983.66$ & $1,001,633,849,66$ & $583,386,995,66$ & $559,384,989,66$ & $568,382,983,66$ & $525,636,995,66$ & $566,886,995,66$ & $511,639,001,66$ & $486,889,001,66$ \\
\hline
\end{tabular}

Monthly Actual - Program Team

\begin{tabular}{|c|c|c|c|c|c|c|c|c|c|c|c|c|}
\hline & $\mathrm{IDR}$ & IDR & IDR & IDR & IDR & IDR & IDR & IDR & IDR & $\overline{\mathrm{IDR}}$ & $\overline{\mathrm{IDR}}$ & IDR \\
\hline $\begin{array}{l}\text { Syread } \\
\text { method }\end{array}$ & PO1 & P02 & P03 & PO4 & P05 & PO6 & P07 & PQB & PO9 & P10 & P11 & P12 \\
\hline Menthly & $400,546,258.00$ & $416,546,258.00$ & $464,546,258.00$ & $488,546,258.00$ & $496,546,258.00$ & $496,546,258.00$ & $472,546,258.00$ & $488,546,258.00$ & $480,546,258.00$ & $480,546,258.00$ & $488,546,258.00$ & $488,546,258.00$ \\
\hline Mantilly & $16,983,161.34$ & $17,661,561.34$ & $19,696,761.34$ & $20,714,36134$ & $21,053,561.34$ & $21,053,561,34$ & $20,035,961.34$ & $20,714,361.34$ & $20,375,161.34$ & $20,375,161.34$ & $20,714,361.34$ & $20,714,361.34$ \\
\hline Meruthly & $3,397,086,00$ & $3,754,674,00$ & $4,827,438.00$ & $5,363,820.00$ & $5,542,614,00$ & $5,542,614,00$ & $5,006,232.00$ & $5,303,820.00$ & $4,827,438.00$ & $4,827,438.00$ & $5,363,820.00$ & $5,363,820,00$ \\
\hline Merritly & $9,120,000.00$ & $10,080,000.00$ & $12,960,000.00$ & $16,400,000.00$ & $14,880,000.00$ & $14,880,000.00$ & $13,440,000.00$ & $14,400,000.00$ & $12,960,000.00$ & $12,960,000.00$ & $14,400,000.00$ & $14,400,000.00$ \\
\hline Menthly & $86,450,000.00$ & $79,800,000.00$ & $73,150,000.00$ & $79,800,000.00$ & $59,850,000.00$ & $63,175,000.00$ & $53,200,000.00$ & $56,525,000.00$ & $63,175,000.00$ & $61,180,000.00$ & $63,840,000.00$ & $53,200,0000.00$ \\
\hline Monthly & $210,000,000.00$ & $227,500,000.00$ & $262,500,000.00$ & $236,250,000.00$ & $35,000,000.00$ & $122,500,000.00$ & $96,250,000.00$ & $140,000,000.00$ & $122,500,000.00$ & $131,250,000.00$ & $131,250,000.00$ & $131,250,000.00$ \\
\hline All at once & & & & & $528,546,258.00$ & & & & & & & \\
\hline Nill at once & $640,997,000,00$ & & & & & & & & & & & \\
\hline \multirow[t]{2}{*}{ Manเal } & $10,000,000.00$ & $10,000,000,00$ & $10,000,000.00$ & $10,000,000.00$ & $5,000,000.00$ & $10,000,000,00$ & $10,000,000.00$ & $10,000,000,00$ & $10,000,000.00$ & $10,000,000.00$ & $10,000,000.00$ & $10,000,000.00$ \\
\hline & $1,377,493,505,34$ & $765,342,493,34$ & $847,680,457,34$ & $855,074,439,34$ & $1,166,418,691,34$ & $733,697,433.34$ & $670,478,451,34$ & $735,549,439,34$ & $714,383,857,34$ & $721,138,857,34$ & $734,114,439,34$ & $723,474,439,34$ \\
\hline
\end{tabular}

Furthermore, the discussion in this paper is structured as follows: The second section discusses several theories that are relevant to the topic of this research. The third section describes the methodology used, while section 4 presents the results and discussion of the main findings. At the end, namely section 5 will conclude the discussion as a whole. 


\section{Theory}

\subsection{Non-profit organizations}

Non-profit organizations aim to support an issue that is attracting public attention and is carried out without having a commercial purpose or aiming for profit [5]. Based on PSAK No. 45 it is known that non-profit organizations obtain resources from donations from members and other donors who do not expect any compensation from the institution. Even though non-profit organizations are not profit-oriented, this organization needs to prepare financial reports in accordance with the format of financial statements of non-profit organizations in Indonesia based on PSAK No. 45 published by IAI 2000.

The ultimate goal of nonprofit financial management is generally to maximize the distribution of donations from donors while minimizing the expenditure of funds to support the operational activities of the organization. There are things that can be controlled from business processes in nonprofit organizations by reducing unnecessary expenses such as ornamental plant rental, reducing newspaper variations, and even adjusting the communication budget based on average usage each month, for example, the initial budget per month is Rp 1 million, but actually the average use is only Rp 500 thousand per month, then the budget can be reduced and have an impact on cost savings every month.

The following are the characteristics of non-profit institutions [5]:

- There's no ownership as in business organizations in general

- Producing an item or service that is not intended to make a profit alone, if there is a profit then it never distributed to the owners of the organization

- Resources or funds that can come from donors who do not wish to benefit from what has been given

\subsection{Absenteeism}

The general definition of absenteeism is unplanned absence, even though the work is scheduled. Employees can be absent at work for various reasons or just deciding to be rebellious as a sign of registering some concerns especially associated with job dissatisfaction in the workplace. Absenteeism in the workplace is catastrophic as it hinders performance and results[27]. There are unseen and often unforeseen costs due to absenteeism, namely increased oversight time, additional staff, overtime, temporary staff hiring, administration, training, insurance, the effects of reduced service provision and loss of business. These invisible costs may be double the wage costs. The absenteeism effect is 
most pronounced when there are jobs that are interdependent with each other. With complex processes, requiring expertise and technology, operations cannot proceed without a complete staffing composition.

A study clearly shows that there is a negative correlation between absenteeism and cost reduction[6]. The study found that with a higher level of absenteeism, and staff turnover has been shown to increase the costs incurred by the organizations. In this study also found that there are a lot of cost reduction in an organization through the implementation of work-life balance policies. Reducing staff turnover results in lower costs, because recruitment requires a lot of direct costs such as job advertisements, interviews and indirect costs such as loss of knowledge and institutional contacts. Staff retention also reduces training costs, because having staff join longer in the organization increases the rate of return on investment for training that has been provided.

\subsection{Workload}

The negative impact of excess workload that is not in accordance with the ability of the workforce causes a decrease in the quality of work due to physical fatigue and decreased concentration, self-supervision, work accuracy so that work results do not comply with standards[7].

The workload pressure can be positive, and this leads to the satisfaction of work-life balance among employees[8]. Employees who positively perceive the workload will understand workload as a challenge not as pressure, and this will make the employee motivated to achieve tasks with good performance, on time so that employees will feel satisfied and have a commitment to the company. This expectation is difficult to achieve if employees have a negative perception of workload.

The research shows very clearly that there is a negative correlation between workload and cost reduction[6]. This study found that with the increase in workload, it was proven to increase the costs that organizations must incur. Ergonomic balance theory[9] states that work fatigue is caused by an imbalance between work capacity and workload factors. If not addressed, it will cause fatigue due to work and cause other problems such as work accidents and reduce work productivity.

\subsection{Job satisfaction}

Job satisfaction is a complex emotional reaction and is a result of encouragement, desires, demands and expectations of employees to work that is connected with the reality felt by employees, giving rise to a form of 
emotional reaction in the form of feelings of pleasure, satisfaction, or feelings of dissatisfaction reflected by work morals, discipline, and work performance[10][11]. If employees feel unsatisfied with their work, employees can leave their jobs, often complain, disobey, steal items belonging to the organization, avoid some of their work responsibilities, and so forth[12].

A study proves that job satisfaction can bring innovative ideas to employees[13]. Employees can be more loyal to the organization. Employees will also be more satisfied if they get what they expect with an efficient worklife balance so that they can work effectively and efficiently. Demographics related to gender, age, education, marital status, number of family members and income level can also be factors that influence job satisfaction.

Several factors can influence job satisfaction, including supervision, leadership attitude, work itself, fairness among employees, accuracy in the placement of work skills, organization and management, colleagues, employee finance, work conditions and guarantees and employee welfare[10][11][14]. Research shows very clearly that there is a positive correlation between job satisfaction and cost reduction[6]. The higher job satisfaction, the higher cost reduction in organization.

\subsection{Cost Reduction}

The overhead costs incurred by an organization are indeed influenced by the level of productivity generated by employees in terms of doing their work, while the level of productivity is strongly influenced by the work-life balance of their employees. Positive impacts resulting from work-life balance include increased performance, productivity, motivation, work involvement and organizational commitment[15][16]. While the negative impacts include absenteeism, employee turnover, work stress, tardiness, and absenteeism (Frone et al., 1997)[17].

The following 4 analysis of activities that can be done in terms of cost reduction[18]:

- Reduction of activities. Reduce the time or effort needed to do the activity. For example, simultaneous engineering reduces time to market.

- Abolition of activities. Eliminate all activities. For example, using the application to eliminate the need to prepare purchase orders and check invoice payments.

- Selection of activities. Choose inexpensive alternatives from a series of design alternatives. These alternatives require different equipment, settings and other resources and require different costs. 
- Division of Activities. Make changes that allow sharing with other products to produce economies of scale. Managing activities is the core of activitybased costing and activity-based management. If you focus on reducing costs, it can lead to wrong decisions.

The most effective and efficient way to do cost reduction is to evaluate which cost factors are priorities, especially related to staff retention. So not by running any program that can reduce organizational costs, because usually the cost savings in the short term may succeed, but it has consequences for the long term.

Actually, not all costs are considered bad. It should also be considered in terms of the benefits and cost analysis of each program that will be run. No problem if there are additional costs, but it can provide output or benefits far greater than the costs incurred. The function of the budget directly related to Cost Reduction is to influence and motivate employees to always take effective and efficient actions for the purpose of the organization.

\section{Method}

The model used in this research is as shown below:

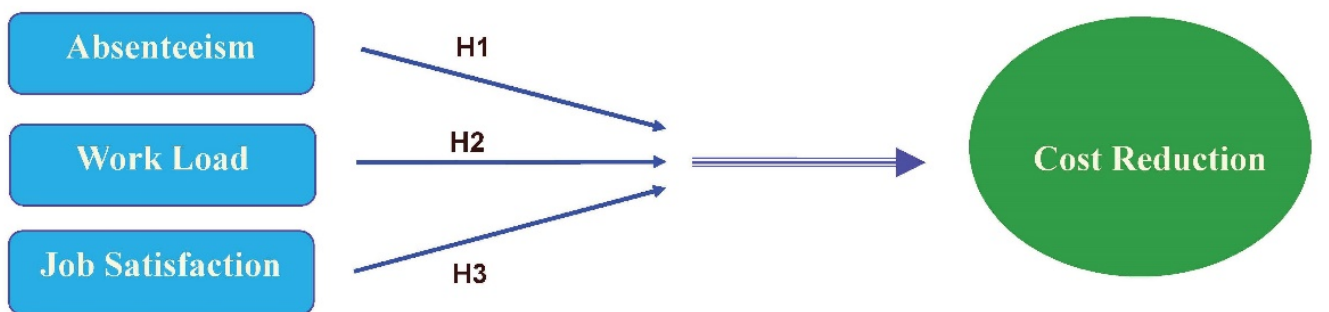

Figure 3.1 Research Conceptual Model

This study approached the abovementioned problem by using descriptive and causal associative research methods. Descriptive problem formulation is related to the statement of each variable in the study. Whereas causal associative has the main objective to find out the effect of absenteeism, workload and job satisfaction (exogenous variable) on cost reduction (endogenous variables). Data analyzed were units of data originating from individual IFRC staff, collected through questionnaire research instruments using a Likert scale.

H1: Absenteeism has a significant negative effect on cost reduction 
$\mathrm{H} 2$ : Workload has a significant negative effect on cost reduction

H3: Job satisfaction has a significant positive effect on cost reduction

The population in this study is the staff working at IFRC CCST Indonesia. Meanwhile, the sample taken in this study consisted of staff from the Jakarta office, Palu Operations and Lombok Operations. The number of research samples taken were 201 samples from the results of the questionnaire distributed to 225 IFRC staff. Sampling technique using a questionnaire technique with a Likert scale and literature study for each variable. While the data source used is primary data, i.e. data obtained directly from the research object. Respondents are usually asked to rate how much they agree with the statement given by the researcher[19]. The range of values used in this study is 1 to 5, with details (1) strongly disagree, (2) means not agree, (3) means neither, (4) means agree, and (5) means strongly agree.

Table 3.1. Questions on Absenteeism

\begin{tabular}{|c|l|}
\hline Kode & \multicolumn{1}{|c|}{ Item } \\
\hline AB1 & High absenteeism rates cause labor turnover \\
\hline AB2 & The level of absence increases the cost of overtime benefits \\
\hline AB3 & Absence interferes with organizational workflow \\
\hline AB4 & Absence and turnover of workers reduces the quality of production \\
\hline
\end{tabular}

Table 3.2 Questions on Workload

\begin{tabular}{|l|l|}
\hline Kode & \multicolumn{1}{|c|}{ Item } \\
\hline WL1 & I feel that too many deadlines in my work are difficult to fulfill \\
\hline WL2 & I work long hours even on holidays \\
\hline WL3 & $\begin{array}{l}\text { My daily activities are affected due to workload (such as exercise, } \\
\text { mealtime, and bedtime) }\end{array}$ \\
\hline WL4 & I like to wake up at night because of problems at work \\
\hline
\end{tabular}

Table 3.3 Questions on Job Satisfaction

\begin{tabular}{|c|l|}
\hline Kode & \multicolumn{1}{c|}{ Item } \\
\hline JS1 & I feel satisfied in terms of working with my colleagues \\
\hline JS2 & $\begin{array}{l}\text { Organizational support for the welfare of its staff is satisfactory according } \\
\text { to workload and responsibility }\end{array}$ \\
\hline JS3 & I feel satisfied with the work that I do \\
\hline JS4 & $\begin{array}{l}\text { I can strike a balance between work and personal demands, so I don't think } \\
\text { about leaving work }\end{array}$ \\
\hline
\end{tabular}

In examining the research model, this study employs SEM (Structural Equation Model) method using Lisrel 8.8 software. The SEM method was chosen because: (1) It can estimate a series of regression equations separately, 
but interdependently, based on structural models used in statistical programs; (2) SEM method can measure variables that have two roles at the same time (dependent variable and independent variable); (3) SEM method is appropriate to be used for confirmatory analysis research, with the aim to test and confirm the theory; (4) SEM method is also suitable for research involving hypothetical causal relationships in research[20].

Descriptive analysis is used to provide information about the characteristics of the research variable by providing a description of the data seen from the mean, standard deviation, maximum, minimum, variant, sum, and range[21]. In this research descriptive analysis is used to find general description of the demographic characteristics of respondents such as gender, age, marital status, last education, and employment agreement status. Descriptive analysis is also carried out on each variable to see the distribution of respondents' answers.

\section{Validity and Reliability Test}

Each latent variable that is processed by SEM data has several indicator variables, and it's modeled as a factor that underlies the indicator variable, also called loading factor. The relationship between indicator variables and latent variables was analyzed through Confirmatory Factor Analysis (CFA). The results of the CFA analysis were obtained through a match test, namely the validity and reliability tests. This compatibility test is carried out for each construct[22].

Validity is the extent to which the developed measurement tool can measure the concept of the study conducted[20]. There are three types of validity tests that can be done, namely (1) content validity to determine how well the depiction of dimensions and elements of a concept, (2) criterion related validity, and (3) construct validity to determine the level of compatibility of the results obtained from the measuring instrument with theory used in testing. First of all a validity test was performed on all variables used in this study, using the Lisrel software and measurement items can be said to be valid if the Standardized Factor Loading (SLF) value $\geq 0.5$ [20].

The reliability of a measuring instrument illustrates the extent to which the gauge is free of bias so that it can make measurements in a stable and consistent manner[23]. Reliability tests were also carried out on all variables used in this study, using Lisrel software, with indicators to measure the degree of reliability using construct reliability measures (CR) and variance extracted measures (VE). The CR value is obtained from the sum of the squares of the factor loading for each construct and the number of error variances for a construct. A variable is called having a good level of reliability if the value of 
$\mathrm{CR} \geq 0.70$. However, $\mathrm{CR}$ values between $0.6-0.7$ can also be called reliable, if other indicators of validity of the construct show good results[20]. In addition, the reliability indicator can also be seen through the value of VE with a standard match $\geq 0.5$ [20]. If the Variance Extracted value is below 0.5, it is still adequate, provided the resulting CR value is greater than 0.5 [24].

The construct reliability value is derived from the square of the total loading standard (sum) divided by the square of the total standard loading value plus the sum error value. Where the standard loading value is derived from the standardized loading value for each indicator (AMOS, Lisrel output results). While the error (e) comes from the measurement error of each indicator: (1Loading2). The cut off value of the construct reliability test is accepted or (fails to be rejected) if the value is $>0.70$, but if the research is still explanatory, values below 0.7 are still accepted.

\section{Model Match Test}

Model fit test is used in measuring how well a particular model is to produce covariance matrices among indicator variables. This test consists of 3 parts, namely absolute fit indices, incremental fit indices, and parsimony fit indices. Absolute fit indices are direct measurements to see how well the model proposed by researchers in reproducing observed data can be measured from various fit indices such as goodness-of-fit-index (GFI), root mean square error of approximation (RMSEA), root mean square residual (RMR), and standardized root mean residual (SRMR). Incremental fit indices measure how well the model under study is in accordance with the baseline model (the most common is the null model). Some incremental fit indices that are often used are normed fit index (NFI), tucker lewis index (TLI), comparative fit index (CFI), and relative noncentrality index (RNI). Parsimony fit indices aims specifically to provide information about the best model compared to other competing models by considering its compatibility with its complexity. Parsimony fit indices can be seen through the adjusted goodness of fit index (AGFI) and parsimony normed fit index (PNFI) values[20].

Through SEM, researchers can answer research questions that are dimensional (ie measuring what indicators of a concept) and regression (measuring the influence or degree of relationship between factors that have been identified dimensions). According to the rules of thumb[20], the model compatibility test must be seen from multiple indicators that include a minimum of $x 2$ values along with df, an absolute fit index (GFI, RMSEA, or SRMR), an incremental fit index (CFI or TLI ), one goodness-of-fit index (GFI, CFI, or TLI), and one badness-of-fit index (RMSEA or SRMR) [20]. Standard values for model suitability tests [20] and [22] can be seen in table 3.4. 
Tabel 3.4 Goodness of fit Index[20]

\begin{tabular}{ll}
\hline Goodness of fit index & \multicolumn{1}{c}{ Cut-of Value } \\
\hline X2 - Chi-square & Expected to be low \\
Significance & $\geq 0,05$ \\
Probability & $\leq 0,08$ \\
RMSEA & $\geq 0,90$ \\
GFI & $\geq 0,90$ \\
AGFI & $\leq 2,00$ \\
CMIN/DF & $\geq 0,95$ \\
TLI & $\geq 0,94$ \\
CFI & \\
\hline
\end{tabular}

\section{Results and Discussion}

Absenteeism Variable consists of four statement indicators. Table 4.1 presents the statistic descriptive of each of the element. Overall, Absenteeism has an average total value of 4.208 which means it is categorized as high.

Table 4.1 Descriptive Statistical of Absenteeism Variable

\begin{tabular}{|c|c|c|c|c|c|c|}
\hline & $\mathrm{N}$ & Min & Max & Mean & $\begin{array}{l}\text { Std. } \\
\text { Deviation }\end{array}$ & $\begin{array}{l}\text { Total } \\
\text { Mean }\end{array}$ \\
\hline $\mathrm{AB} 1$ & 201 & 1.00 & 5.00 & 3.81 & 53.82 & 4.208 \\
\hline $\mathrm{AB} 2$ & 201 & 2.00 & 5.00 & 4.31 & 60.93 & \\
\hline $\mathrm{AB} 3$ & 201 & 2.00 & 5.00 & 4.23 & 59.88 & \\
\hline $\mathrm{AB} 4$ & 201 & 2.00 & 5.00 & 4.48 & 63.39 & \\
\hline
\end{tabular}

Workload Variables consist of 4 statement indicators, which are shown by Table 4.2. Overall, the workload has an average total value of 3.805, which means it belongs to the high category.

Table 4.2 Descriptive Statistical of Workload Variable

\begin{tabular}{llrrrrr}
\hline & N & Minimum & Maximum & Mean & Std. Deviation & Total Mean \\
\hline WL1 & 201 & 2.0 & 5.0 & 3.63 & 51.36 & \\
WL2 & 201 & 2.0 & 5.0 & 3.53 & 48.88 & 3.805 \\
WL3 & 201 & 2.0 & 5.0 & 3.63 & 51.43 & \\
WL4 & 201 & 1.0 & 5.0 & 4.42 & 62.55 & \\
\hline
\end{tabular}

Job Satisfaction Variable consists of four indicator indicators as shown by Table 4.3. Overall the job satisfaction variable has an average total value of 4.162 which means it is in the high category. 
Table 4.3 Descriptive Statistical of Job Satisfaction Variable

\begin{tabular}{ccccccc}
\hline & $\mathrm{N}$ & Minimum & Maximum & Mean & Std. Deviation & Total Mean \\
\hline JS1 & 201 & 2.0 & 5.0 & 4.07 & 57.62 & \\
JS2 & 201 & 2.0 & 5.0 & 4.31 & 60.93 & 4.162 \\
JS3 & 201 & 2.0 & 5.0 & 4.13 & 58.40 & \\
JS4 & 201 & 1.0 & 5.0 & 4.14 & 58.54 & \\
\hline
\end{tabular}

\section{Validity and Reliability Test}

In the case of the indicators of Absenteeism, namely AB1, AB2, AB3 and $\mathrm{AB} 4$, the results of the calculation of standardized loading factors showed that not all items meet the standard loading factor $\geq 0.50$, except $A B 4$. Considered $\mathrm{AB} 1, \mathrm{AB} 2, \mathrm{AB} 3$ must be removed from the model, while AB4 is valid.

Table 4.4 Validity Test Absenteeism Variable

\begin{tabular}{lcccr}
\hline Latent variable & Item & Loading Factor & Error & Conclusion \\
\hline Absenteeism & AB1 & 0.21 & 0.96 & Not Valid \\
& AB2 & 0.05 & 1.00 & Not Valid \\
& AB3 & 0.14 & 0.98 & Not Valid \\
& AB4 & 0.93 & 0.13 & Valid \\
\hline
\end{tabular}

From the results of reliability testing for absenteeism variables, since only 1 item is left, there is no need to calculate the CR (construct reliability) and VE (variance extracted) manuals.

Meanwhile, the results of data processing on the workload variable which has 4 indicators (observable variables) namely WL1, WL2, WL3 and WL4. The results of the standardized loading factor calculation show that all statement items meet the standardized loading factor $\geq 0.50$ except WL4. So WL4 must be removed from the model, whereas WL1, WL2, Valid WL3.

Table 4.5 Validity Test Workload Variable

\begin{tabular}{lcrrr}
\hline Latend variable & Item & Loading Factor & Error & Conclusion \\
\hline Workload & WL1 & 0.98 & 0.04 & Valid \\
& WL2 & 0.96 & 0.07 & Valid \\
& WL3 & 0.97 & 0.05 & Valid \\
& WL4 & 0.11 & 0.99 & Not Valid \\
\hline
\end{tabular}

From the results of reliability testing for workload variables, the 3 items are reliable because they have a construct reliability value of $0.98>0.50$, and an extracted variance value of 0.94 . Thus, the results of item tests are valid and reliable, then the research instruments are feasible to use for data collection in research.

Based on the results of data processing on job satisfaction variables that have 4 indicators (observed variables), namely JS1, JS2, JS3 and JS4. The 
results of the standardized loading factor calculation show that not all statement items meet the standardized loading factor $\geq 0.50$ except JS1. So JS2, JS3 and JS4 must be removed from the model, while JS1 is Valid.

Table 4.6 Validity Test Job Satisfaction Variable

\begin{tabular}{lrrrr}
\hline Latent variable & Item & Loading Factor & Error & Conclusion \\
\hline Job Satisfaction & JS1 & 0.59 & 0.65 & Valid \\
& JS2 & 0.41 & 0.83 & Not Valid \\
& JS3 & 0.39 & 0.85 & Not Valid \\
& JS4 & 0.14 & 0.98 & Not Valid \\
\hline
\end{tabular}

From the results of reliability testing for job satisfaction variables, because there is 1 item left, there is no need to calculate manually the CR (construct reliability) and VE (variance extracted).

\section{Structural Test model}

Furthermore, a model compatibility test is performed to ensure that the research model can represent the data by comparing theory with existing data. Based on the test results of the suitability of the research model that can be seen in table 4.8 , it is known that almost all indicators show the research model is included in the good fit category.

Table 4.7 Model Match Test Results

\begin{tabular}{lccl}
\hline & Cut-off value & Result & Remarks \\
Goodness-of-fit & $\geq 0.90$ & 0,91 & Good fit \\
\hline Goodness of Fit Index (GFI) & $<0.08$ & 0.078 & Good Fit \\
Standardized Root Mean & & & \\
Square Residual (SRMR) & $\geq 0.90$ & 0,90 & Good fit \\
Normed Fit Index (NFI) & $\geq 0.90$ & 0,92 & Good fit \\
Comparative Fit Index (CFI) & $\geq 0.90$ & 0,92 & Good fit \\
Incremental Fit Index & & & \\
\hline
\end{tabular}

Source: Output Lisrel 8.8

\section{Hypothesis Test with SEM method}

In the next stage, hypothesis testing is carried out using the Structural Equation Model (SEM) method. Testing is done with LISREL software using the Lisrel 8.8 application through path analysis, the aim is to determine the strength of the relationship on the model.

In this study a hypothesis test was performed by looking at the t-value because the standard deviation of the study population was unknown. This study uses a level of confidence of 0.05 and a total sample of 201, so the critical value 
in this study is 1.96 for the one-tailed hypothesis[25]. Figure 4.1 and Figure 4.2 below show the value of standardized loading factor and t-values of the research model.

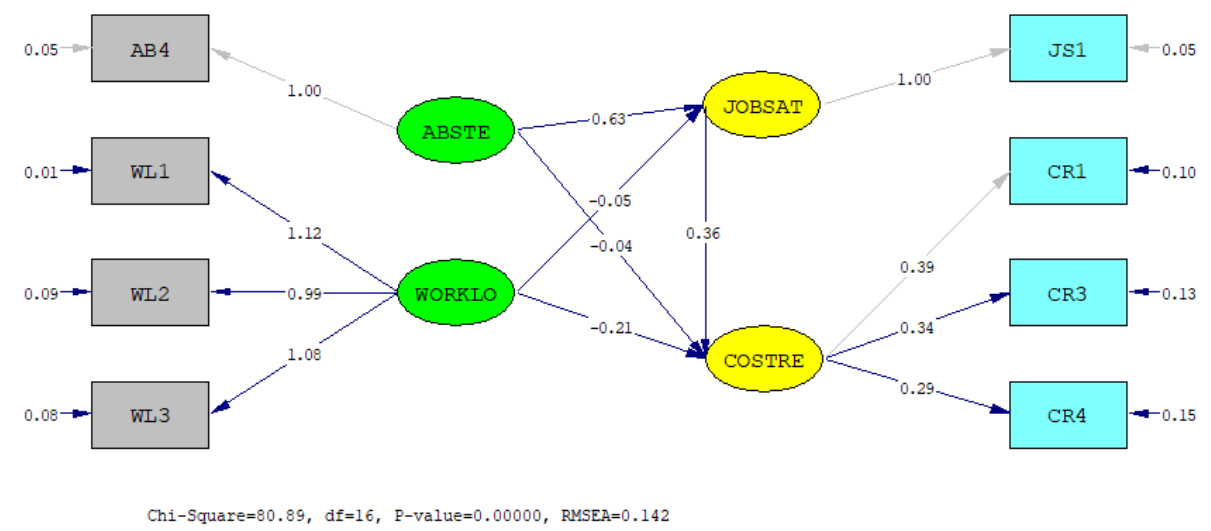

Figure 4.1 Standardized Loading Factor Research Model Source: Lisrel 8.8 processed by researchers

After testing the hypothesis, the results can be seen from the output issued by Lisrel. The significance of the relationships between variables can be seen in Figure 4.2 path diagram of the t-value model.

On a significant effect, the t-value must be greater than the t-table, with a value greater than 1.96 (significance at the 0.05 level). Based on the H1 hypothesis, absenteeism has a significant negative effect on cost reduction. Then from the test results in Figure 4.2 shows that the resulting t-value of $-0.24<$ 1.96. This means showing incompatibility with the initial hypothesis so that $\mathrm{H} 1$ is rejected.

Next, the researcher tests the $\mathrm{H} 2$ hypothesis, and it is shown that workload has a significant negative effect on cost reduction. From the t-value between workload and cost reduction it turns out to have a value smaller than 1.96 which is -2.68 . This shows the incompatibility with the initial hypothesis, so that finally this $\mathrm{H} 2$ is rejected.

Based on the $\mathrm{H} 3$ hypothesis, job satisfaction has a significant positive effect on cost reduction, then from the test results as can be seen in Figure 4.2 shows that the resulting t-value of $4.92>1.96$. This means that in accordance with the initial hypothesis so that $\mathrm{H} 3$ fails to be rejected. 


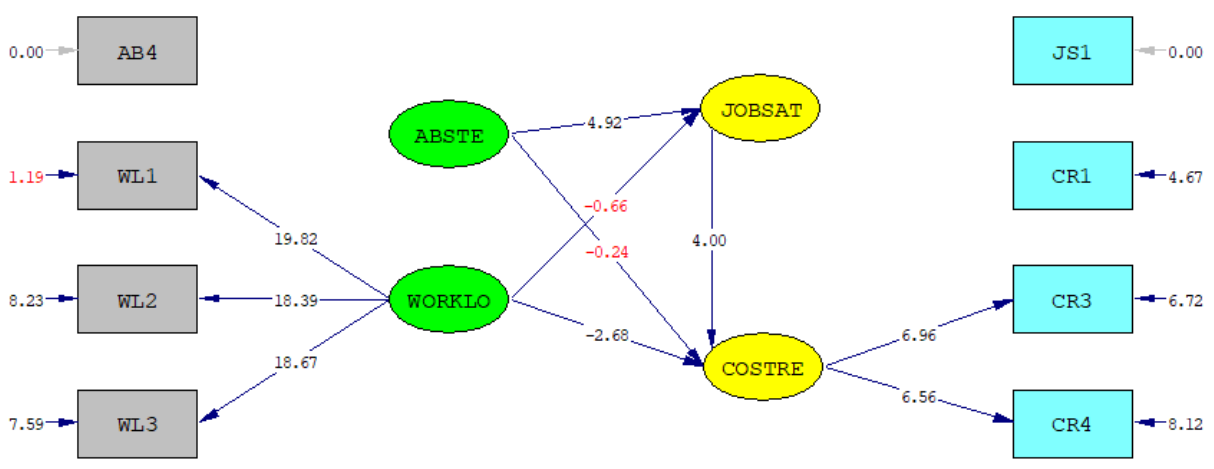

Chi-Square $=80.89, \mathrm{df}=16, \mathrm{P}$-value $=0.00000, \mathrm{RMSEA}=0.142$

Figure 4.2 T-Value Research Model Source : Lisrel 8.8 processed by Researchers

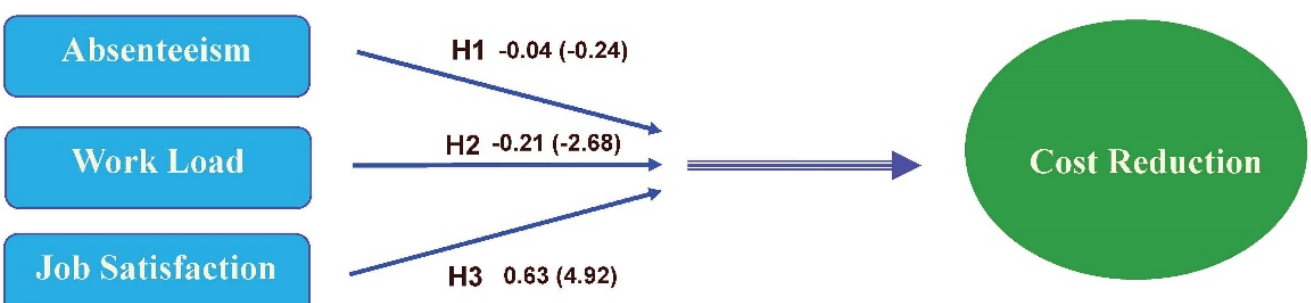

Figure 4.3 Path Analysis Test Results Source: data processed by Researchers

Table 4.9 Test Results

\begin{tabular}{|c|c|c|l|l|}
\hline Hypotheses & T-Value & Coefficient & \multicolumn{1}{|c|}{ Test Result } & \multicolumn{1}{|c|}{ Conclusion } \\
\hline H1 AB -> CR & -0.24 & -0.04 & Not significant & H1 is rejected \\
\hline H2 WL -> CR & -2.68 & -0.21 & Not significant & H2 is rejected \\
\hline H3 JS - > CR & 4.92 & 0.63 & Significant & $\begin{array}{l}\text { H3 is failed to be } \\
\text { rejected }\end{array}$ \\
\hline
\end{tabular}

Source : Lisrel 8.8 Data processed by Researchers

\section{Overall analysis}

When a disaster or health emergencies happen, requests for humanitarian assistance from IFRC rise sharply, at that time, staff are faced with high workloads and prone to be overwhelmed and can trigger fatigue for staff. This requires an optimal management system that can manage a balanced workload so that it can control work-life balance problems that staff may face. The IFRC 
organization understands very well that staff is a valuable asset, therefore IFRC always gives appreciation commensurate with the capabilities of its staff. However, the performance of each staff is strongly influenced by different individual demographic factors such as age, gender, marital status, educational level, as well as psychological factors, work systems, existing workloads, support and motivation from the organization for the welfare of the staff alone.

It can be concluded that the role of the organization needs to be increased in the work-life balance program to reduce the level of absenteeism through flexibility in terms of working time, a very adequate number of annual leave of 24 days and also working from home policies for certain circumstances, availability of nursery rooms for breastfeeding, break out rooms to release work fatigue, and family-friendly policies such as special leave (maternity leave, leave for male staff to accompany a wife to give birth, leave with accompanying parents / close relatives who are sick, etc.), informal activities such as outbound (skills development activities), gymnastic programs, yoga and other hobby distribution while providing diverse coffee needs in the office pantry (clean kitchen) office.It becomes an important point that will benefit the organization in terms of cost reduction by not having to incur additional costs to recruit additional staff so that the work target can be achieved.

In addition to absenteeism, workload also does not have a significant negative effect on cost reduction. An uneven distribution of staff workload has a continuing impact caused by this problem. However, based on descriptive analysis in this study, it shows that IFRC has done a good division of work and achieved targets in accordance with the competence and authority of each position, so that IFRC has controlled the costs incurred by the organization.

While on job satisfaction variable this study shows effective results, involvement and all related to benefits such as reducing leave intentions, less absenteeism, reducing the number of delays and increasing performance and productivity. All of which contribute to cost control and organizational growth. On the cost reduction variable, the results are in line with a study[26] which investigates the relationship between workload and cost reduction and shows a negative influence.

The flow of cost reduction and profit increase in the end is not the final goal, but rather leads to an increase in the main profit - the results of interest[6]. Cost reduction can come from a variety sources, including lower wages, lower absenteeism, lower staff turnover or reduced energy and office costs. In setting the scale of these costs, the potential scope of work-life balance program to improve the business balance sheet. Several studies have also found reductions in average salaries at the initial level, related to work-life balance programs 
offered by companies. Thus, some or all of the work-life balance policy costs are offset by lower wage costs.

It can be concluded that decreasing the level of absenteeism, balanced workload and high job satisfaction increases cost reduction as can be seen its significant effect on variable cost data in table 1.2. And the organizational management must continue to control it, one of which is through the implementation of work-life balance program for IFRC CCST Indonesia's staff.

\section{Conclusion}

1. In this study shows that absenteeism has an insignificant negative effect on cost reduction at IFRC. Work-life balance program need to be improved to reduce the level of absenteeism. Generally, the high absenteeism shows an imbalance work-life balance, and incur extra costs to recruit additional workers or daily workers to reach the set time target.

2. In this study shows that workload has an insignificant negative effect on cost reduction at IFRC. IFRC has done a good division of work and achieved targets in accordance with the competence and authority of each position, so that IFRC has controlled the costs incurred by the organization.

3. In this study shows effective results on job satisfaction and it has a significant positive effect on cost reduction at IFRC and all related to benefits such as reducing intention to leave, less absenteeism, reducing the number of delays and increasing performance and productivity. Because job satisfaction makes the staff feel that their work contributions are highly valued and get appropriate compensation.

4. There are limitations to the study conducted using this questionnaire method, the researcher did not sit with the respondent when filling out the questionnaire, so the researcher could not conduct in-depth interviews with the respondent to confirm the results of the study. Furthermore, this research was not conducted in several different organizations so it cannot be ascertained that the results of this study will always be the same if it is carried out on different respondents, samples, variables, locations and times. 


\section{References}

[1] Lazar Ioan., Osoian Croduta. dan Ratiu Patricia. 2010. The Role of Work-life Balance Practices in Order to Improve Organizational. European Research Studies. Vol. 13, pp. 201-214.

[2] Yasbek Philippa. (2004). The business case for firm-level work-life balance policies: a review of the literature.

[3] Bersay. (2016), "İnsan kıymetleri politikamı" (Our human assets policy), available at: http://www.bersay.com.tr/tr/insan-kiymetleri-politikamiz (accessed 3 March, 2016).

[4] Rao, V. S. P., Assets of an Organization. HRM Management. 2010

[5] Anitasari, Nuraini. 2018. Artikel Lembaga Non Profit, Benarkah Tidak Membutuhkan Profit?. available at: https://zahiraccounting.com/id/blog/ lembaga-non-profit/_ (accessed $15 \mathrm{Jul}, 2020$ ).

[6] Deborah, Smeaton., Ray Katg., Knight Genevieve. Costs and benefits to business of adopting worklife balance working practices (2014).

[7] Winaya Kuna. 1989. Manajemen Sumber Daya Manusia (Lanjutan). Edisi Ketiga, Fakultas Ekonomi Universitas Udayana. Denpasar

[8] Robbins, S. P. 2003. Perilaku Organisasi, Jilid 2. PT. Indeks Kelompok Gramedia. Jakarta.

[9] Sudiajeng L., Tarwaka B., 2004. Ergonomi untuk Keselamatan, Kesehatan Kerja dan Produktivitas. Surakarta: Uniba Press.

[10] Sutrisno E. (2017). Manajemen Sumber Daya Manusia. (Cetakan kesembilan). Jakarta: Kencana.

[11] Hasibuan, M. S. (2017). Manajemen Sumber Daya Manusia. (Cetakan kedua puluh satu). Jakarta: Bumi Aksara.

[12] Robbins P. Stephen \& Judge Timothy A. 2017, Organizational Behaviour, Edisi 13, Jilid 1, Salemba Empat, Jakarta.

[13] Yadav, R. K. \& Yadav, S. S. (2014). Impact of work life balance and stress management on job satisfaction among the working women in public sector banks. International Letters of Social and Humanistic Sciences, 26, 6370.

[14] Sedarmayanti. (2017). Perencanaan dan Pengembangan Sumber Daya Manusia untuk Meningkatkan Kompetensi, Kinerja, dan Produktivitas Kerja

[15] Cegarra-Leiva D., Sánchez-Vidal M.E. and Cegarra-Navarro J.G. (2012), "Understanding the link between work life balance practices and organizational outcomes in SMEs", Personnel Review, Vol. 41 No. 3, pp. 359-379.

[16] Wayne J. H., Musisca N. and Fleeson W. (2004), "Considering the role of personality in the workfamily experience: Relationships of the big five to work-family conflict and facilitation”, Journal of Vocational Behavior, Vol. 64 No. 1, pp. 108-130.

[17] Kim H.K. (2014). Work-Life Balance and Employees Performance: The Mediating Role of Affective Commitment. Global Business and Management Research: An International Journal, 6, 37-51.

[18] Turney, Peter B. B., "How Activity-Based Costing Helps Reduce Costs," in Emerging Practices in Cost Management, ed. Barry J. Brinker (Boston: Warren Gorham Lamont, 1992), p. D5-3. With permission.

[19] Jackson Chris. (2009). Jackson-5 scales of revised Reinforcement Sensitivity Theory (r-RST) and their application to dysfunctional real world outcomes. Journal of Research in Personality.

[20] Hair Joseph F. Jr., Black William C., Babin Barry J. \& Anderson Rolph P., Multivariate Data Analysis, $7^{\text {th }}$ Ed. 2014. 
[21] Ghozali I. (2007). Aplikasi Analisis Multilavare dengan Program SPSS. Semarang: Badan Penerbit Universitas Diponegoro.

[22] Wijanto S. H. (2008). Structural Evaluation Modeling dengan LISREL 8.8. Graha Ilmu, Yogyakarta.

[23] Sekaran U., \& Bougie R. (2016). Research methods for business: A skill building approach. New York. John Wiley \& Sons.

[24] Fornell C. \& Larcker D. F. (1981). Evaluating structural equation models with unobservable variables and measurement error. Journal of Marketing Research, 18 (1), 39-50.

[25] Lind D. A., Marchal W. G. \& Wathen S. A. (2012). Statistical techniques in business \& economics. New York, NY: McGraw-Hill/Irwin.

[26] Cole D., Panchanadeswaran S. \& Daining C. (2004). Predictors of job satisfaction of licensed social workers: Perceived efficacy as a mediator of the relationship between workload and job satisfaction. Journal of Social Service Research, 31(1), 1-12.

[27] Badubi, Reuben. Akhunjonov, Umidjon. Obrenovic, Bojan. (2017). A Critical Risk Analysis of Absenteeism in the Work Place. 